\title{
Change and cause analysis of water resources in Fengtai district of Beijing in recent 61a (from 1956 to 2016)
}

\author{
Qin Jing ${ }^{\mathrm{a}}$, Niu Wen-long, Lu Wei, Zhao Ling-yun, Gao Wen-lian \\ Engineering Design and Research Center, China Institute of Water Resources and Hydropower Research, Beijing 100044, China
}

\begin{abstract}
The calculation of water resources is the fundamental basis for legitimate utilization, effective protection, optimal configuration and optimal dispatch of water resources. Affected by climate change, economic development, and population expansion, the amount of water resources in Fengtai district, one of the central urban areas of Beijing, has undergone major changes. By comparing the results of the second investigation and evaluation of water resources (1956-1998), the paper analyzes the dynamic changes and causes of surface water resources, ground water resources and total water resources in Fengtai district in recent 61a (1956-2016). The results show that the surface water resources of Fengtai district in recent 61a is 37.978 million $\mathrm{m}^{3}$, which is 2.572 million $\mathrm{m}^{3}$ less than the previous investigation; the ground water resources is 92.959 million $\mathrm{m}^{3}$, a decrease of 13.848 million $\mathrm{m}^{3}$; the total water resources is 104.981 million $\mathrm{m}^{3}$, which is 13.830 million $\mathrm{m}^{3}$ less than the previous investigation. The gradual reduction of regional atmospheric precipitation is the main cause of the decline in surface runoff and rainfall infiltration recharge. At the same time, the continuous water-cutting of Yongding River (the biggest inflow river in Fengtai) since 2000 and the anti-seepage project implemented in 2010 further reduced the infiltration of river infiltration .
\end{abstract}

\section{Introduction}

Water is a fundamental natural and strategic economic resource, a controlling factor of the ecosystem, and an important support and guarantee for economic and social development. Water will become the most important global resource issue in the 21 st century ${ }^{[1]}$. As a developing country, China is a country with severe drought and water shortage. The total amount of water resources is about 2.8 trillion cubic meters, and the per capita water resource is only 2,034 cubic meters, which is only $1 / 4$ of the world's per capita water resource. China is one of the countries with the most lack of per capita water resource in the world ${ }^{[2-3]}$. Beijing is China's political, cultural, international exchange, science and technology innovation center, which carries important strategic capital functions, but the per capita water resource is only $1 / 20$ of the national average, and the per capita water resource is less than 100 cubic meters, which is a serious shortage. The water area is also one of the most severely water-deficient cities in the world ${ }^{[4-5]}$. Fengtai District is one of the six districts in the central city of Beijing. The per capita water resource is only $1 / 2$ of that in Beijing ${ }^{[6]}$. The shortage of water resources will become the main factor restricting the economic development of the region.

Fengtai District conducted the second water resources survey and evaluation at the beginning of this century. The time in the survey was from 1956 to 1998. However, in recent years, due to climate change, sustained and rapid development of the social economy, and the expansion of population, the water resources in Fengtai District have undergone large changes. It is urgent to analyze and calculate the existing water resources in this region. Through comparing the results of previous surveys, this paper analyzes the dynamic changes of surface water resources, groundwater resources and total water resources of Fengtai District in the near 61 years (1956-2016), which aims to better guide the future water resources of Fengtai District. The rational use of water resources, effective protection, optimal allocation, and optimal dispatching also provide theoretical basis and data support for Fengtai District's advanced planning of "Beijing Urban Master Plan (2016-2035)".

\section{Overview of Fengtai District}

Fengtai District is in the southwest of Beijing City (Figure. 1). The total area of this area is $305.9 \mathrm{~km}^{2}$, which ranks 3rd in the city's six districts ${ }^{[7]}$. From north to south,the main stream of Yongding River is divided into two parts: Hedong area and Hexi area. Hexi is mainly low mountains, hills and terraces with an area of $126 \mathrm{~km}^{2}$; Hedong area is Yongding River alluvial plain with an area of $179.9 \mathrm{~km}^{2}$.

There are 43 rivers in Fengtai District and 16 rivers in the district. Among them, 8 rivers are mainly located in the Daqing River system in Hexi area, and the other 8 rivers belong to the Bei Canal water system in Hedong area (Table. 1).

\footnotetext{
a Corresponding author: qinjing@iwhr.com
} 


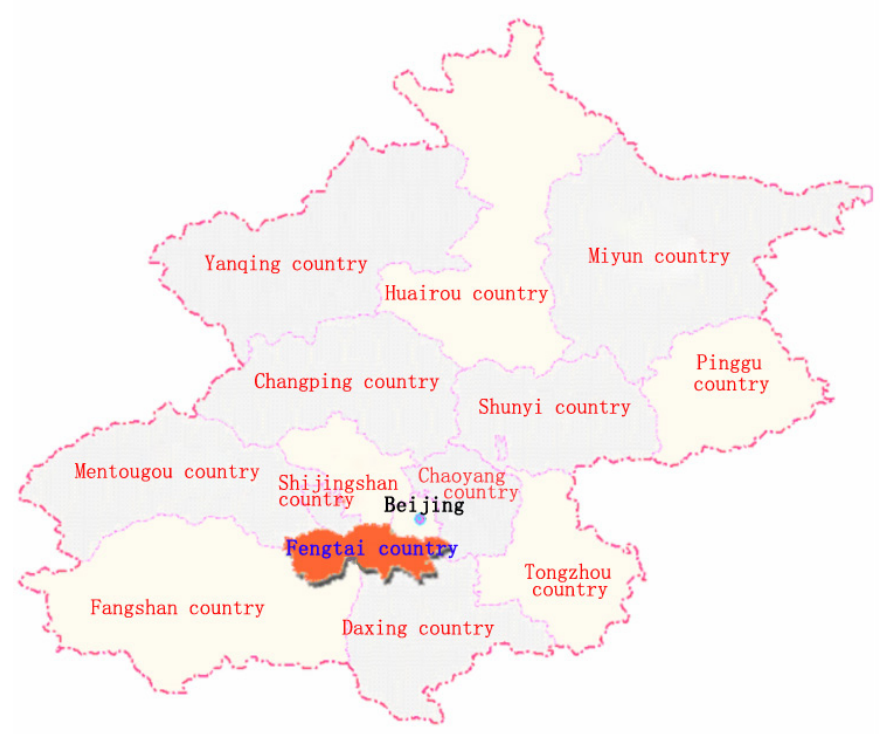

Figure 1. Geographical position of Fengtai district.

Table 1. Water system of Fengtai district.

\begin{tabular}{|c|c|c|c|c|c|}
\hline Water system & Serial number & River name & Water system & Serial number & River name \\
\hline \multirow{8}{*}{ Daqing river(Hexi district) } & 1 & $\begin{array}{l}\text { Xiaoqing river south } \\
\text { ditch }\end{array}$ & \multirow{8}{*}{$\begin{array}{c}\text { Beiyun river(Hedong } \\
\text { district) }\end{array}$} & 1 & Liangshui river \\
\hline & 2 & $\begin{array}{l}\text { Xiaoqing river north } \\
\text { ditch }\end{array}$ & & 2 & Shuiya ditch \\
\hline & 3 & Xiaoyaba river & & 3 & Fengcao river \\
\hline & 4 & Jiuzi river & & 4 & Macao river \\
\hline & 5 & Python cow river & & 5 & Han river \\
\hline & 6 & Dianqi river & & 6 & Xiaolong river \\
\hline & 7 & Mang cow river & & 7 & Baoli ditch \\
\hline & 8 & Xiaoqing river & & 8 & $\begin{array}{c}\text { Huangtugang irrigation } \\
\text { canal }\end{array}$ \\
\hline
\end{tabular}

\section{Amount of water resources}

\subsection{Surface water resources}

The amount of surface water resources refers to the amount of dynamic water that can be updated year by year in rivers, lakes, glaciers and other surface water bodies formed by precipitation, which is expressed by the annual runoff of rivers ${ }^{[8]}$. The calculation of surface water runoff in Fengtai District is mainly based on the surface runoff from the domestic production area.
However, due to the lack of hydrological stations in Fengtai District and the lack of long-series measured runoff data, the regional main rainfall station is near 61 years (1956 2016). Rainfall data and runoff coefficients are calculated.

Due to the mountainous areas and hills in Hexi area, the impact of human activities and urban development and construction is small, and the underlying surface conditions are not changed much. The runoff coefficient adopts 0.25 , which is the runoff coefficient of in the previous water resources survey and evaluation. The average runoff coefficient of Hedong area is 0.21 , according to the average runoff coefficient calculated by 
precipitation and runoff data of Liangshuihe Dahongmen Hydrological Station from 2011 to 2016 (Table 2), which is greater than the previous survey value of 0.16 . The reason is that the Hedong area is an urban construction area. In recent years, the development degree is relatively fast, and the impervious area of the underlying surface has increased significantly.

Table 2. Calculation of runoff coefficient based on Dahongmen hydrometric station in Liangshui River of Fengtai district.

\begin{tabular}{|c|c|c|c|c|}
\hline Year & Precipitation (mm) & Runoff (million $\left.\mathbf{~ m}^{\mathbf{3}}\right)$ & Runoff depth (mm) & $\begin{array}{c}\text { Runoff } \\
\text { coefficient }\end{array}$ \\
\hline 2011 & 868.07 & 15.652 & 119.04 & 0.14 \\
\hline 2012 & 1060.34 & 18.055 & 137.32 & 0.13 \\
\hline 2013 & 643.94 & 19.797 & 150.57 & 0.23 \\
\hline 2014 & 472.00 & 16.036 & 121.97 & 0.26 \\
\hline 2015 & 557.78 & 17.023 & 129.47 & 0.23 \\
\hline 2016 & 960.93 & 31.059 & 236.23 & 0.25 \\
\hline Mean & 760.51 & 19.604 & 149.10 & 0.21 \\
\hline
\end{tabular}

The change trend of surface water resources in Fengtai District from 1956 to 2016 was analyzed (Figure. 2 ). The annual variation of surface water resources was obvious, but the overall trend was downward, and the surface water production decreased slightly. Calculated for many years (1956 2016), the average surface water resources were 37.78 million cubic meters, which was 2.572 million cubic meters compared with the previous results.

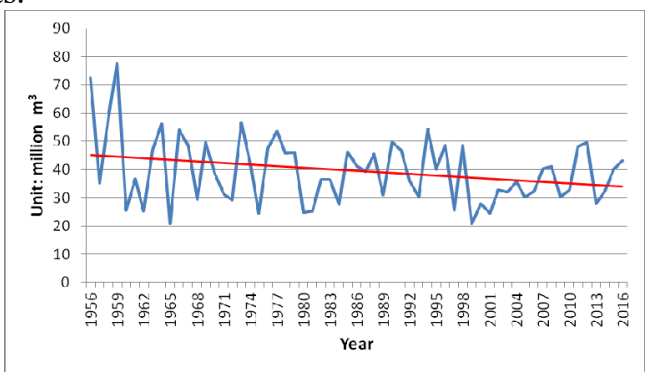

\subsection{Groundwater resources}

The total recharge of groundwater in the plain area of Fengtai District mainly includes rainfall infiltration replenishment, river seepage recharge, lateral inflow recharge, canal and canal infiltration replenishment and well recharge. For the calculation method of various groundwater infiltration, refer to the "Water Resources Evaluation" (the 2nd Edition), which will not be detailed here. According to calculation, the groundwater resources of near 61 years in Fengtai District are shown in Table 3.

The use of sections to divide the text of the paper is optional and left as a decision for the author. Where the author wishes to divide the paper into sections the formatting shown in Table 2 should be used.

Figure 2. Variation trend of surface water resources in recent 61a in Fengtai district.

Table 3. Comparison of groundwater resources in recent $61 \mathrm{a}$ in Fengtai district with previous survey results.

\begin{tabular}{|c|c|c|c|c|c|c|}
\hline Year & $\begin{array}{c}\text { Rainfall } \\
\text { infiltration } \\
\left(\text { million } \mathbf{m}^{3}\right)\end{array}$ & $\begin{array}{c}\text { River } \\
\text { channel } \\
\text { leakage } \\
\left(\text { million m } \mathbf{m}^{3}\right)\end{array}$ & $\begin{array}{c}\text { Irrigation } \\
\text { canal } \\
\text { infiltration } \\
\left(\text { million } \mathbf{m}^{3}\right)\end{array}$ & $\begin{array}{c}\text { Lateral } \\
\text { recharge } \\
\left(\text { million } \mathbf{m}^{3}\right)\end{array}$ & $\begin{array}{c}\text { Groundwater } \\
\text { discharge } \\
\left(\text { million } \mathbf{m}^{3}\right)\end{array}$ & $\begin{array}{c}\text { Total } \\
\left(\text { million } \mathbf{m}^{3}\right)\end{array}$ \\
\hline $1956-1998(43 a)$ & 33.940 & 47.594 & 0.742 & 21.741 & 2.79 & 106.807 \\
\hline $1956-2016$ (61a) & 31.332 & 34.779 & 2.317 & 21.741 & 2.79 & 92.959 \\
\hline
\end{tabular}

It can be seen from the Table 3 that the average precipitation infiltration from 1956 to 2016 in the sequence year is less than that in the second water resources survey, and the canal infiltration increases, and the total groundwater resources are smaller than the second water. The resource survey and evaluation decreased by 13.848 million cubic meters.

\subsection{Total water resources}

The total amount of water resources represents the maximum potential of the available water resources under current natural conditions, thus providing a basis for the rational development and utilization of water resources. Surface water and groundwater are interconnected and transformed into each other. The river runoff derived from part of the groundwater discharge, and part of the total groundwater recharge, part of the infiltration of surface waters. So, the surface water resources and groundwater resources cannot be directly as a total amount of water resources, the amount of repeated water converted from each other should be deducted ${ }^{[8]}$. which is

$$
W=R+Q-D
$$

In the formula: $W$-The amount of total water resources, unit: 104 cubic meters;

$R$ - The amount of surface water resources, unit: 104 cubic meters; $Q$ - The amount of groundwater resources, unit: 104 cubic meters; $D$ - The amount of repetitive resources of 
surface water and groundwater, unit: $10^{4}$ cubic meters.

After calculation (Table 4), and deducting the surface water and groundwater repetitive amount, the total amount of water resources in Fengtai District near 61 years is 104.981 million cubic meters, which is 13.83 million cubic meters less than the previous survey results. The main contribution is the reduction of groundwater resources.

Table.4 Comparison of total water resources in Fengtai District between the previous investigation and the recent 61a

\begin{tabular}{|c|c|c|c|c|}
\hline Year & $\begin{array}{c}\text { Surface water } \\
\text { resource } \\
\left(\text { million } \mathbf{m}^{3}\right)\end{array}$ & $\begin{array}{l}\text { Groundwater } \\
\text { resources } \\
\left(\text { million } \mathbf{m}^{3}\right) \\
\end{array}$ & $\begin{array}{l}\text { repeated amount } \\
\quad\left(\text { million } \mathbf{m}^{3}\right)\end{array}$ & $\begin{array}{l}\text { Total water } \\
\text { resources } \\
\left(\text { million } \mathbf{m}^{3}\right)\end{array}$ \\
\hline 1956-1998 (43a) & 40.550 & 106.807 & 28.546 & 118.811 \\
\hline 1956-2016 (61a) & 37.978 & 92.959 & 28.351 & 104.981 \\
\hline
\end{tabular}

\section{Cause analysis}

\subsection{Reduced atmospheric precipitation}

Both surface water resources and groundwater resources are dynamic waters that can participate in the modern water cycle and can be updated. Therefore, changes in rainfall have a crucial impact on the evolution of total water resources. This paper analyzes the variation of precipitation in a long sequence (1956 2016) and three short sequences (1956 1998, 2001 2016, 1981 2016) to

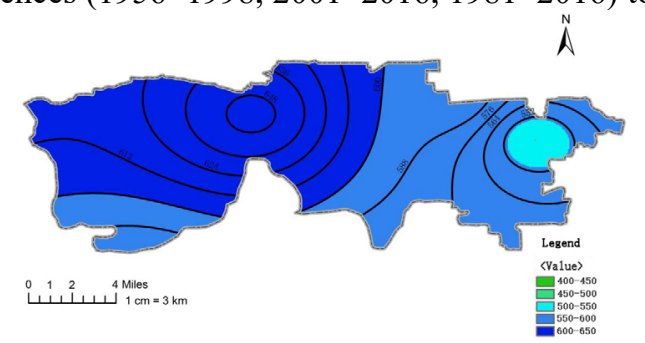

Figure.3 Contour distribution of mean annual rainfall in Fengtai district from 1956 to 1998

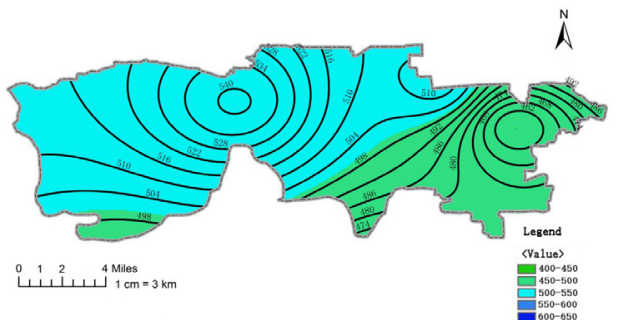

Figure.5 Contour distribution of mean annual rainfall in Fengtai district from 2001 to 2016 study the amount of precipitation on water resources. Impact.

Considering the topography and geomorphology of Fengtai District is more obvious from northwest to southeast, and the rainfall station is unevenly distributed in this area. In this paper, the Tyson polygon is used to calculate the average rainfall in the area, and the ArcGIS software is used to plot the Kriging interpolation contour map of rainfall ${ }^{[9-10]}$. The calculation results are shown in Figure. 3, Figure. 4, Figure. 5, Figure. 6, and Table 5, respectively.

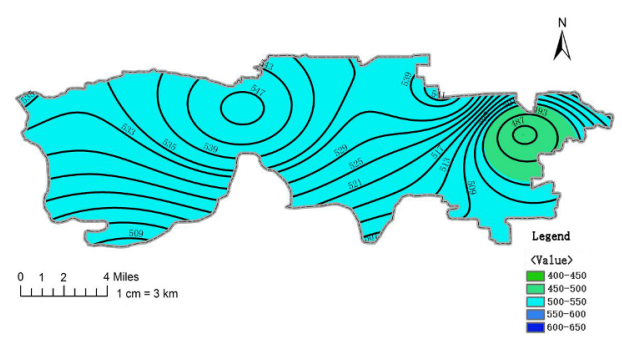

Figure.4 Contour distribution of mean annual rainfall in Fengtai district from 1981 to 2016

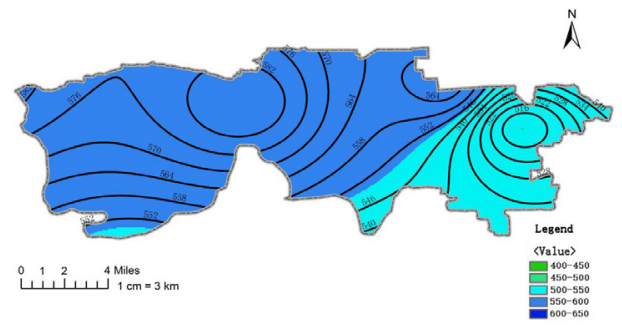

Figure.6 Contour distribution of mean annual rainfall in Fengtai district from 1956 to 2016

Table.5 Comparison of annual average rainfall over different periods in Fengtai district

\begin{tabular}{|c|c|c|c|c|}
\hline $\begin{array}{c}\text { Year } \\
\text { Rainfall }\end{array}$ & $1956 \mathrm{a} \sim 2016 \mathrm{a}$ & $1956 \mathrm{a} \sim 1998 \mathrm{a}$ & $1981 \mathrm{a} \sim 2016 \mathrm{a}$ & $2001 \mathrm{a} \sim 2016 \mathrm{a}$ \\
\hline Rainfall $(\mathrm{mm})$ & 569.5 & 599.5 & 534.3 & 516.7 \\
\hline
\end{tabular}

From the four different years of average annual rainfall contour maps, it can be seen that the rainfall from 1981 to 2016 and 2001 to 2016 is significantly decreased compared with the rainfall from 1956 to 1998 and from 1956 to 2016. And the precipitation distribution from 2001 to 2016 is less than the rainfall from 1981 to 2016. In addition, it can be seen from the series of pictures that the overall distribution of precipitation gradually decreases from northwest to southeast, and is directly related to the topographical features of Fengtai District.

Table 5 shows that the precipitation from 2001 to 2016 decreased by $17.6 \mathrm{~mm}$ from 1981 to 2016, and decreased by $65.2 \mathrm{~mm}$ from 1981 to 2016 compared with 1956 to 1998 , which visually reflects the second water. Since the evaluation of resource surveys, the average 
precipitation is small, which is the main reason for the decrease in total water resources.

\subsection{Yongding River cutoff}

Yongding River is the largest transit river in Fengtai District. Since 2000, it has continued to cut off water. Particularly, Yongding River implemented the "Yongding River Green Ecological Development Belt Construction Project" in 2010. In order to maintain the anti-seepage project on the water surface of the river, further the actual infiltration replenishment of the Yongding River has been reduced, which has reduced the infiltration of groundwater in Fengtai District.

The calculation of the infiltration of the Yongding River is based on the Lugou Bridge and Gu'an as the upper and lower sections respectively. After deducting the amount of water drawn from the interval, the factor of reduction is 0.9 (according to the evaporation loss), and the difference in permeability of the river section is considered. The calculation results are shown in Table 5. The results show that the infiltration of the Yongding River Fengtai District is mainly concentrated in 19782000. Except for the water cuts in a few years from 1992 to 1994 and 1999, there are certain river sections in other years. Infiltration, the infiltration of the Fengtai section of the period from 1978 to 1984 and 1995 to 1996 exceeded 10 million cubic meters; but since 2000, the Yongding River has been shut down in successive years, and the groundwater infiltrated into the Fengtai District is no longer counted. Compared with the second water resources survey and evaluation results, the infiltration capacity of Yongding River in Fengtai District (2013 million cubic meters) decreased by 8.99 million cubic meters, which is one of the main factors leading to the decrease of total water resources in Fengtai District. The infiltration of the Yongding River in Fengtai District over the years can be seen in the Table 6 .

Table.6 Annual infiltration of yongding river in Fengtai district

\begin{tabular}{|c|c|c|c|c|c|}
\hline Year & $\begin{array}{c}\text { Lugou bridge annual } \\
\text { runoff } \\
\left(\text { million } \mathrm{m}^{3}\right)\end{array}$ & $\begin{array}{l}\text { Gu'an annual runoff } \\
\quad\left(\text { million } \mathbf{m}^{3}\right)\end{array}$ & $\begin{array}{l}\text { Interval introduction } \\
\quad\left(\text { million } \mathbf{m}^{3}\right)\end{array}$ & $\begin{array}{l}\text { Interval infiltration } \\
\quad\left(\text { million } \mathbf{m}^{3}\right)\end{array}$ & $\begin{array}{c}\text { Infiltration in Fengtai } \\
\text { district } \\
\left(\text { million } \mathbf{m}^{3}\right)\end{array}$ \\
\hline 1978 & 185.00 & 0.06 & 0.00 & 184.94 & 49.71 \\
\hline 1979 & 594.00 & 244.00 & 0.00 & 350.00 & 94.08 \\
\hline 1980 & 525.00 & 54.30 & 0.00 & 470.70 & 126.52 \\
\hline 1981 & 82.40 & 0.00 & 0.00 & 82.40 & 22.15 \\
\hline 1982 & 66.90 & 0.00 & 0.00 & 66.90 & 17.98 \\
\hline 1983 & 123.00 & 0.00 & 0.00 & 123.00 & 33.06 \\
\hline 1984 & 43.20 & 0.00 & 0.00 & 43.20 & 11.61 \\
\hline 1985 & 7.09 & 0.00 & 0.00 & 7.09 & 1.91 \\
\hline 1986 & 1.82 & 0.00 & 0.00 & 1.82 & 0.49 \\
\hline 1987 & 0.49 & 0.00 & 0.00 & 0.49 & 0.13 \\
\hline 1988 & 4.51 & 0.00 & 0.00 & 4.51 & 1.21 \\
\hline 1989 & 10.01 & 0.00 & 0.00 & 10.01 & 2.69 \\
\hline 1990 & 7.36 & 0.00 & 0.00 & 7.36 & 1.98 \\
\hline 1991 & 0.54 & 0.00 & 0.00 & 0.54 & 0.15 \\
\hline 1992 & 0.00 & 0.00 & 0.00 & 0.00 & 0.00 \\
\hline 1993 & 0.00 & 0.00 & 0.00 & 0.00 & 0.00 \\
\hline 1994 & 0.00 & 0.00 & 0.00 & 0.00 & 0.00 \\
\hline 1995 & 91.83 & 10.50 & 0.00 & 81.33 & 21.86 \\
\hline 1996 & 337.10 & 172.20 & 50.00 & 114.90 & 30.88 \\
\hline 1997 & 19.50 & 0.00 & 0.00 & 19.50 & 5.24 \\
\hline 1998 & 3.80 & 0.00 & 0.00 & 3.80 & 1.02 \\
\hline 1999 & 0.00 & 0.00 & 0.00 & 0.00 & 0.00 \\
\hline 2000 & 3.00 & 0.00 & 0.00 & 3.00 & 0.81 \\
\hline 2001 & 0.00 & 0.00 & 0.00 & 0.00 & 0.00 \\
\hline 2002 & 0.00 & 0.00 & 0.00 & 0.00 & 0.00 \\
\hline 2003 & 0.00 & 0.00 & 0.00 & 0.00 & 0.00 \\
\hline 2004 & 0.00 & 0.00 & 0.00 & 0.00 & 0.00 \\
\hline 2005 & 0.00 & 0.00 & 0.00 & 0.00 & 0.00 \\
\hline 2006 & 0.00 & 0.00 & 0.00 & 0.00 & 0.00 \\
\hline 2007 & 0.00 & 0.00 & 0.00 & 0.00 & 0.00 \\
\hline
\end{tabular}




\begin{tabular}{|c|c|c|c|c|c|}
\hline Year & $\begin{array}{c}\text { Lugou bridge annual } \\
\text { runoff } \\
\left(\text { million } \mathbf{m}^{3}\right)\end{array}$ & $\begin{array}{l}\text { Gu'an annual runoff } \\
\left(\text { million } \mathbf{m}^{3}\right)\end{array}$ & $\begin{array}{l}\text { Interval introduction } \\
\left(\text { million } \mathbf{m}^{3}\right)\end{array}$ & $\begin{array}{l}\text { Interval infiltration } \\
\left(\text { million } \mathbf{m}^{3}\right)\end{array}$ & $\begin{array}{c}\text { Infiltration in Fengtai } \\
\text { district } \\
\left(\text { million } \mathbf{m}^{3}\right)\end{array}$ \\
\hline 2008 & 0.00 & 0.00 & 0.00 & 0.00 & 0.00 \\
\hline 2009 & 0.00 & 0.00 & 0.00 & 0.00 & 0.00 \\
\hline 2010 & 0.00 & 0.00 & 0.00 & 0.00 & 0.00 \\
\hline 2011 & 0.00 & 0.00 & 0.00 & 0.00 & 0.00 \\
\hline 2012 & 0.00 & 0.00 & 0.00 & 0.00 & 0.00 \\
\hline 2013 & 0.00 & 0.00 & 0.00 & 0.00 & 0.00 \\
\hline 2014 & 0.00 & 0.00 & 0.00 & 0.00 & 0.00 \\
\hline 2015 & 0.00 & 0.00 & 0.00 & 0.00 & 0.00 \\
\hline 2016 & 0.00 & 0.00 & 0.00 & 0.00 & 0.00 \\
\hline Total & 2106.55 & 481.06 & 50.00 & 1575.49 & 423.48 \\
\hline Average & 55.44 & 12.66 & 1.32 & 41.46 & 11.14 \\
\hline
\end{tabular}

\section{Conclusion}

(1) As the statistical analysis of Fengtai District data from 1956 to 2016 shows, the surface water resources of Fengtai District in the past 61 years was 37.78 million cubic meters, which was 2.572 million cubic meters less than the previous survey; the groundwater resources were 92.959 million cubic meters, a decrease of 13.848 million cubic meters; The total amount of water resources was 104.981 million cubic meters, which was 13.83 million cubic meters less than the previous survey.

(2) The regional atmospheric precipitation is gradually decreasing. The average annual rainfall in the past 16 years is $516.7 \mathrm{~mm}$, which is $14 \%$ less than the multi-year average of the previous survey $(599.5 \mathrm{~mm}$ in the 1956-1998 series), which is caused by surface runoff and the main reason for the decrease in rainfall infiltration recharge.

(3) The impact of human activities on the amount of water resources in Fengtai District has increased. The Yongding River has been shut off since 2000. The antiseepage project implemented in 2010 has led to a significant reduction in underground infiltration recharge, which in turn has affected the amount of groundwater resources.

\section{Acknowledgement}

This work was supported by the Ministry of Water Resources budget project for 2018(SJ0149B222018).

\section{References}

1. Wang Hao. China's water resources face challenges. N. Beijing sci-tech report, 4 (2011)

2. Zhao Yue, Jiang Jinhe, Li Fuqiang. Analysis of influencing factors of water use efficiency in China. J. Water conservancy economy, 36, 1 (2018)

3. Wang Zhanjun, Li Lipeng, Liu Ting. Analysis of water resource status and development trend. J. Research on urban construction theory, 17: 180 (2017)

4. Su Yanxi. Beijing's per capita water resources are only 1/20 of the national average. N. China Youth News, 3 (2017)

5. Fan Yingying, Liu Yong, Guo Huaicheng etc. Study on the influence of Beijing water resource policy on water resource carrying capacity. J. Resources science, 27, 5: 113-119 (2005)

6. Liu Quanlai. Problems and countermeasures in the development and utilization of water resources in Fengtai district. J. Beijing water, 6: 39-41 (2010)

7. Zhang Jianguo, Liu Quanlai. Water resources protection and conservation and utilization plan in the 12th five-year plan of Fengtai district. M. Beijing Fengtai water bureau, (2011)

8. Wang Chao, LI Ju. Construction and practice of water resources quantity evaluation system in yunnan water resources bulletin. J. Hydrological, 37, 3:75-80 (2017)

9. Yan Zhenmei, Mu Guohong. Calculation of mean rainfall on river basin surface based on tyson polygon method. J. Water conservancy technology and economy, 23, 1:19-22 (2017)

10. Peng Siling, Deng Min, Huang Binghu, Xu Bangshu. Isohydric based on ArcEngine. J. Geographic information world, 8, 2:79-83 (2010) 